\title{
Constructive Investing
}

CAN INFRASTRUCTURE INVESTING DELIVER ON POTENTIAL?

\section{By Sherree DeCovny}

One of the few issues that Donald Trump and Hillary Clinton generally agreed on during their 2016 presidential election campaigns was the need to rebuild infrastructure. In its "2017 Infrastructure Report Card," the American Society of Civil Engineers (ASCE) gave US infrastructure a D+ gradeunchanged from its last report card in 2013. Moreover, it estimated that about $\$ 4.59$ trillion over 10 years is needed to upgrade US infrastructure to a "good state of repair," up

In its 2017 report card, Civil Engineers gave US infrastructure its second straight $D+$ grade.

More infrastructure spending could open up significant opportunities for core infrastructure companies and related businesses.

The sheer amount of capital needed means that the pool for investing in infrastructure will likely grow. the American Society of from \$3.6 trillion over eight years in 2013. The ASCE also estimated that there is a $\$ 2$ trillion, 10-year investment gap, meaning that all government and private investment must increase from $2.5 \%$ to $3.5 \%$ of GDP by 2025 .

Skeptics might argue that the ASCE has been issuing bad grades for the last two decades, and many impressive projects have been completed across the US during that time. Despite the state of the infrastructure, the economy has continued to grow. And perhaps civil engineers have a financial interest in making gloomy forecasts to drum up support for spending on projects that benefit them.

Still, practically every modern US presidential administration has faced an infrastructure conundrum. In his first term, President Obama designated several projects as "shovel ready," or able to immediately receive stimulus funding through the Recovery and Reinvestment Act of 2009 and begin construction within a few months. The act also created a new tool for municipal financing called Build America Bonds (BABs), which were taxable bonds for which the US Treasury Department paid a direct subsidy of $35 \%$ of the interest costs to the issuer. BABs helped state and local governments finance public capital projects at lower borrowing costs. According to the Treasury Department, more than $\$ 180$ billion of BABs were issued over the lifetime of the program, and state and local governments reaped about $\$ 20$ billion in present-value savings from issuing them. President Obama's fiscal year 2012 budget proposed to reinstate and expand the program (which expired in 2010), but it was not renewed.

Other laws were introduced during the Obama administration to provide federal funding, financing, or technical assistance for infrastructure projects. Among them were the Fixing America's Surface Transportation Act, the Transportation Infrastructure Finance and Innovation Act loan program, the Highway Bill, the Water Infrastructure Improvements for the Nation Act, and the Water Resources Development Act.

Meanwhile, corporate America is growing more frustrated. After participating in a panel at the House Transportation and Infrastructure Committee in February 2017, Fred Smith, chairman and CEO of FedEx, stated publicly that US roadways are deteriorating because the federal gasoline and diesel tax has not been increased since 1994 .

"There are 20 interstate highway projects that are in the queue at the [Department of Transportation]. They may not be shovel ready, but they are engineered, and with the appropriate funding, they could be built," Smith said.

Not everyone agrees with Smith's views on gas tax. Randal O'Toole, a senior fellow with the Cato Institute, has noted that since the early 2000s, Congress has diverted more than $\$ 55$ billion of gas taxes to non-highway projects; thus, increasing the gas tax would not necessarily result in spending on projects that would benefit highway travelers. Gas taxes, along with tolls, pay for state highways, but they do not pay for city and county roads, which still need subsidies from other taxes. With increasingly fuel-efficient cars appearing on the road more and more, gas taxes do not make sense anymore.

More infrastructure spending could open up significant opportunities for core infrastructure companies and related businesses, propelling US equity indexes higher. That said, the S\&P Global Infrastructure Index, which tracks 74 companies from around the world -22 of which are from the US-rose only $2 \%$ in the four months after the election. Individual company performance has varied. Shares in such companies as Boise Cascade, Argan, and NV5 Global have risen by double digits in percentage terms. The performance has been more modest at other firms, from Duke Energy and American Water Works to Martin Marietta and Vulcan Materials Company, none of which has seen an overall share increase larger than $4 \%$ in the four months since Election Day.

Interestingly, Trump's promise to accelerate the boom in natural gas and bring back coal jobs seems out of step with current trends. A significant amount of research and development in listed and private companies focuses on sustainable solutions and disruptive innovation in engineering and construction, renewable energy, and materials science.

For example, Tesla's mission is to accelerate the world's transition to sustainable energy. The company offers a line of electric cars, as well as batteries that store solar energy. 
Ambri, a private company led by Donald Sadoway, a professor of materials chemistry at MIT, is also working on gridlevel renewable energy storage. His team has developed a liquid-metal battery that can be connected to a source of electricity, such as a wind farm. Ambri has raised more than $\$ 50$ million in venture capital from investors, and commercial models are expected to be deployed soon.

The US has a large listed-utilities sector, and many companies are using more sources of renewable energy and novel forms of energy. To this end, the California Energy Commission is planning to test piezoelectric energy harvesters under the surface of asphalt to capture road vibrations and transmit zero-carbon electricity power from them.

"[Environmental, social, and governance] is going to play into how the investment community deploys their capital going forward," says Fraser Hughes, CEO at Global Listed Infrastructure Organization (GLIO). "There is increasing pressure on pension funds to deploy capital in responsible ways. For example, I imagine a large European pension fund would rather invest money in clean energy versus dirty energy, now and increasingly going forward."

Innovations in materials include Cargill's SafeLane surface overlay, which is designed to improve safety and prolong infrastructure longevity. The epoxy aggregate in the overlay stores de-icing and anti-icing chemicals, such as brine, and releases them when needed. The city of Toledo, Ohio, has installed the overlay on some bridges that were in borderline condition. City officials have stated that the overlay has added about 10-15 years to their lifespans.

Outside the US, MX3D Bridge is working to 3D print a fully functional steel bridge for pedestrians over water in Amsterdam. The project is supported by partners Autodesk, Heijmans, Arcelor Mittal, and Air Liquide; sponsors ABB Robotics, STV, Delcam, Within, and Lenovo; and public partners TU Delft, AMS, and the Amsterdam City Council.

According to Hughes, the Trump administration needs to be smart about putting attractive infrastructure investment regulation in place for the long term. Importantly, the administration needs to think about setting up liquid investible vehicles to generate much-needed private capital from both the US and abroad.

Rebuilding the infrastructure will require massive effort for municipalities, and private investment will be necessary to take up the funding slack. Hughes says that listed-infrastructure investment trusts (InvITs), modeled after real estate investment trusts, could be a viable option. Investors could contribute to rebuilding the country's infrastructure through a tradable instrument while getting exposure to such underlying core infrastructure assets as transportation and utilities. At the same time, investors could benefit from the transparency, regulation, and liquidity of the listed markets, in addition to attractive yields.

"In the GLIO coverage, there are approximately 150 core global listed-infrastructure companies, representing about $\$ 2$ trillion in market capitalization," notes Hughes. "On average, their long-term total return and annualized performance outstrips the returns of the S\&P 500 or MSCI Global Equities, coupled with significantly lower volatility."

The sheer amount of capital needed means that the pool for investing in infrastructure will likely grow and that when it does, well-understood, transparent vehicles will be critical. In the future, a broad range of investors could have access to InvITs; specialist-managed, global listed-infrastructure funds; listed debt funds; and private equity funds. This access would enable investors to successfully build a fully diversified global-infrastructure allocation.

Currently, large insurance companies are looking at listed debt as a way to participate in infrastructure investment. The assets offer long-term cash flows to match the insurers' extended liabilities. Specialist listed-infrastructure funds and exchange-traded funds might appeal to smaller institutional and retail investors. The listed-infrastructure market may be interesting for larger institutions wishing to gain exposure to assets unobtainable in the private market, such as listed US utilities or railroads. Some may want to blend a private/listed-infrastructure exposure or achieve infrastructure exposure for "dry powder" (highly liquid investments) earmarked for future private investment.

The International Monetary Fund estimates that every $\$ 1$ invested in infrastructure could drive $\$ 3$ of output if done efficiently. If the funding gap is not addressed, however, it could have economic consequences for families, businesses, and the overarching economy. According to the US Bureau of Labor Statistics, about 14.5 million Americans work in infrastructure-related jobs, ranging from truck drivers to electricians to civil engineers. Many jobs are located in metropolitan areas and focus on operating infrastructure instead of its construction, design, or governance.

Crumbling infrastructure is not a problem unique to the US. The Organisation for Economic Co-Operation and Development and the McKinsey Global Institute estimate that roughly $\$ 50$ trillion to $\$ 60$ trillion is needed globally for infrastructure projects. That means the US makes up about $10 \%$ of the overall global funding gap. Further, PwC and Oxford Economics estimate that worldwide, infrastructure spending will grow from $\$ 4$ trillion per year in 2012 to more than $\$ 9$ trillion per year by 2025 . Close to $\$ 78$ trillion is expected to be spent on infrastructure globally between 2014 and 2025. Putting the US into context, federal spending on highways totaled $\$ 46$ billion in 2014, according to the US Congressional Budget Office-a drop in the bucket.

"To a certain extent, the globe looks to the US for leadership," Hughes points out. "If it gets the right regulation and investment vehicles in place, there's
KEEP GOING

"Investing for the Double Bottom Line," CFA Institute Magazine (June 2016): www.cfapubs.org

"Building Up Infrastructure," CFA Institute Magazine (November/December 2015): www.cfapubs.org no reason why 10 years down the line we can't look at the US as the [example] for fixing the infrastructure-funding problem."

Sherree DeCovny is a freelance journalist specializing in finance and technology. 